\section{Environmental disclosure analysis of sustainability reports the brazilian and international brewing industry based on Global Reporting Initiative - GRI}

\section{Análise da evidenciação ambiental dos relatórios de sustentabilidade da indústria cervejeira brasileira e internacional com base na Global Reporting Initiative - GRI}

GESTÃO PRODỨC̄̃̃

ISSN 0104-530X (Print) ISSN 1806-9649 (Online)

\author{
Erika Sucena ${ }^{1}$ \\ Marcia Mara de Oliveira Marinho'
}

\begin{abstract}
How to cite: Sucena, E., \& Marinho, M. M. O. (2019). Environmental disclosure analysis of sustainability reports the brazilian and international brewing industry based on Global Reporting Initiative - GRI. Gestão \& Produção, 26(3), e3120. https://doi.org/10.1590/0104-530X3120
\end{abstract}

\begin{abstract}
Environmental disclosure is a tool set that companies use to communicate their environmental performance to stakeholders. The organization Sustainability Report is the main platform to report the company's relationship with the environment in which operates. The Global Reporting Initiative- GRI is a scheme that develops and disseminates guidelines for this kind of account, to standardize and promote international report classification. The brewing industry is actively involved in the Brazilian economy, being a consumer of natural resources in great amounts. Thus, the objective of this article is to evaluate the level of environmental disclosure practiced in the sustainability reports of Brazilian brewering industries. The sample is characterized by the Sustainability Reports of the years 2011 to 2013 of the Brazilian companies: Ambev; Brazil Kirin; Grupo Petrópolis and internationals, Heineken; AB InBev; SABMiller and Heineken Netherlands. It was used four research techniques to analyse the reports: (1) Classification of indicators as the answer; (2) Adherence to treatment or GAPIE-GRI; (3) Effective Disclosure Degree and (4) indicators ranking the contents. Based on the obtained data, it can be concluded that the environmental information disclosure in the Sustainability Reports of the brewering industry, both national and international, has flaws such as: a) low disclosure GRI indicators with full adherence; b) lack of external verification of the documents; c) lack of financial correlation of environmental indicators; d) low quality provided information and e) lack of measurement information.
\end{abstract}

Keywords: Environmental disclosure; Industry brewery; Sustainability reports; GRI; Brazil.

Resumo: A evidenciação ambiental é um conjunto de meios que a empresa adota para comunicar de maneira completa seus escopos ambientais às partes interessadas. O Relatório de Sustentabilidade de uma organização é a principal plataforma para reportar a relação da empresa com o meio ambiente no qual a mesma está inserida. A Global Reporting Initiative- GRI é uma iniciativa que elabora e divulga diretrizes para esse tipo de relato, a fim de padronizar e promover a classificação internacional desses relatórios. O setor industrial cervejeiro participa de forma ativa na economia brasileira, sendo grande consumidor de recursos naturais. Dessa forma, o objetivo dessa pesquisa foi avaliar o nivel da evidenciação ambiental praticada nos relatórios de sustentabilidade das indústrias cervejeiras brasileiras. A amostra caracteriza-se pelos Relatórios de Sustentabilidade dos anos de 2011 a 2013 das empresas brasileiras: Ambev, Brasil Kirin, Grupo Petrópolis e Heineken Brasil e, das representantes internacionais, AB InBev, SAB Miller e Heineken Holanda. Utilizou-se quatro técnicas de pesquisa para a análise dos relatórios: (1) Classificação dos indicadores quanto a resposta; (2) Grau de aderência ou GAPIE-GRI; (3) Grau de Evidenciação Efetiva e (4) Classificação dos indicadores quanto ao conteúdo. Com base nos dados alcançados, pode-se inferir que a divulgação de informações ambientais nos Relatórios de Sustentabilidade do setor cervejeiro,

\footnotetext{
${ }^{1}$ Universidade Federal da Bahia - UFBA, Rua Professor Aristides Novis, 2, CEP 40210-630, Salvador, BA, Brasil, e-mail: sucena.erika@hotmail.com; marma@ufba.br
}

Received Jan. 31, 2017 - Accepted Aug. 20, 2018

Financial support: Fundo de Amparo à Pesquisa do Estado da Bahia - FAPESB. 
tanto o nacional quanto o internacional, possui fragilidades, como a baixa divulgação de indicadores GRI com aderência plena, ausência de verificação externa do documento, a falta de correlação financeira dos indicadores ambientais, o tipo das informações prestadas e a não mensuração das informações.

Palavras-chave: Evidenciação ambiental; Indústria cervejeira; Relatórios de sustentabilidade; GRI; Brasil.

\section{Introduction}

With the growing companies concern about the environment that they are involved with, full disclose about their actions to the organization's stakeholders is needed, in order to inform the measures adopted by the company to manage its environmental impacts and consumption of natural resources.

The Sustainability Report is the main communication tool for the company environmental issues, summarizing the actions and reactions of the company towards the environment and its environmental performance (Trieweiller et al., 2012).

The Global Reporting Initiative (GRI) is an international non-governmental organization, with the mission to promote the standardization and international classification of organizational reports, publishing guidelines for this type of report (GRI, 2013).

The Brazilian brewing sector is a differentiated oligopoly, composed of few but large companies (Borges \& Souza, 2009). The sector has an important participation in the country economy, contributing significantly with the Gross Domestic Product (GDP) and communicating directly with several economy areas, through the consumption of goods and transportation of products (FGV, 2008). Breweries are highly demanding natural resources, especially water, but also energy consumption, raw materials, caustic soda, the generation of solid by-products, recyclable waste, industrial effluents and CO2 emissions (Santos \& Ribeiro, 2005; Pereira \& Lima, 2013; Borges \& Souza, 2009; Vieira, 2014).

Considering the lack of support, provided by the technical literature on the Sustainability Reports of the brewing industry and the importance of a full disclosure about its environmental issues, the following question arise: What is the environmental disclosure level of Brazilian brewing industries sustainability reports compared to this report type in the same sector on international scope?

The research overall objective was to evaluate the level of environmental evidence contained in the Brazilians breweries sustainability reports.

\section{Theoretical reference}

\subsection{Environmental disclosure and sustainability reports}

Environmental accounting is deeply linked to economic and financial aspects as well as its measurements, identifications and clarifications related to environmental protection, preservation and recovery aiming the entity's transparency (Ribeiro, 2010). Thus, for this author, the disclosure is an instrument included in the organization environmental accounting, being a tool that allows the communication of monetary information.

However, for Santos (2011) and Abreu et al. (2008) Environmental Accounting approach, besides the environment, social parameters, reporting in economic terms the actions of organizations about these aspects, as a way to make clear, useful information to Stakeholders about the management and environmental performance adopted by companies. Although they still treat, evidence only in financial terms, Santos (2011) and Abreu et al. (2008) broaden the definition adopted by Ribeiro (2010), since they already present a perspective of use and clarification regarding environmental management and performance adopted by the company in social and environmental scopes.

Santos (2011) and Abreu et al. (2008) still consider that the Environmental Evidence is the environmental information presentation and its disclosure process, where we must use the language that concerns accounting, getting it closer to the organization board, to meet the new challenges and information needs of all stakeholders.

Cormier \& Magnan (2003) and Rover et al. (2012) define Environmental disclosure as an information set that reports the company's performance environmental management (present, past and future), as well as the financial implications of environmental actions and decisions.

In this definition, Cormier \& Magnan (2003) and Rover et al. (2012) already relate the disclosure issue about the organization environmental performance allied to financial problems from decisions related to the environment in a comparative and related way to a basis that expresses the institution performance.

Fraas \& Dawkins (2011) point out that, although the companies number that disclose their environmental performance has increased, this information has a set of information that is lower than expected.

The statement by Fraas \& Dawkins (2011) shows that just pointing out environmental results and goals is not enough for a proper environmental disclosure of a company. The situation of the organization that is reporting itself needs to be inserted in a performance temporal context (past and present) with impacts and future perspectives, being performed in a comparative 
way and presenting a clear metric for the performance measurement reported.

Calixto $(2005,2007)$ believes that environmental disclosure should address the measurement and control of environmental expenditures and should not be restricted to the qualitative information of financial approach. After all, companies that publish their interests, impacts and environmental interventions have more information to declare besides the situation of just considering the important environmental issue to your business strategy and corporate management.

On the other hand, Rosa et al. (2010) approach Environmental Evidentiary in a more transversal way, considering it as a set of means used by companies that have the objective of divulging their actions and relations with the environment to stakeholders, which makes this evidence type individual and focused on meeting the social demands of employees, shareholders and any other party that is interested in the company's relationship with the environment in the short, medium and long term.

Vellani \& Ribeiro (2009) point out that the integration of economic, social and environmental interests is necessary in the current corporate environment due to the need to reconcile profit generation to shareholders and the social and environmental pressures.

These interactions need to be reported to stakeholders in order to make the company's corporate practice clear, its actions and decision-making about the issues that confer on it in the sustainability scopes presented above.

The disclosure of reports is the main way to make public, improve and maintain a good image towards stakeholders, as these reports can represent, in a clear and brief way, the company's relations with the environment in which it is inserted. The honesty and clarity of the company acts when reporting them are extremely important (Trieweiller et al., 2012).

The Global Reporting Initiative (GRI, 2013) defines that the Organizational Sustainability Report is considered a fundamental instrument in the communication of positive and negative environmental impacts, as well as an object of influence in the political and strategic decision making of organizations.

This type of report is responsible for disseminating the economic, environmental, social and governance performance of the reporting organization, thereby increasing the perception of the risks and opportunities they face, improving the company's image and its understanding towards stakeholders, among others reasons (GRI, 2013).

In the Brazilian brewing sector, despite being composed mainly of few but large companies, the disclosure of specific documents that make environmental issues public is still incipient and non-uniform, as Sucena \& Marinho (2014) argue.

\subsection{The Global Reporting Initiative - GRI}

The Global Reporting Initiative (GRI) is an international non-governmental organization, headquartered today in Amsterdam, the Netherlands. It emerged in 1997 as an coalition initiative for Environmentally Responsible Economies (CERES), a North American non-governmental organization that brought together environmental, labor, religious and investor organizations in partnership with the United Nations Environment Program (UNEP) (Leite et al., 2009).

According to GRI (2013), comparability is the basis to evaluate performance and it is absolute crucial that stakeholders can correlate the information contained in reports with the performance of other organizations or other sectors. Or to evaluate the same organization in diferent periods of time, to verify if there was any evolution.

The GRI mission is to promote the organizational reports standardization and international classification. In 2013, GRI released the latest Sustainability Reporting Guide update entitled G4 Guidelines for Sustainability Reporting. In this version, the financial, social and environmental indicators were updated to a most complete disclosure data in comparison with the previous version, for companies to present in their Sustainability Reports (GRI, 2013).

Hahn \& Lüfs (2013) criticize the GRI in relation to company's excessively positivist discourse often used in its reports and the non-publication of negative information omited in this report type.

These authors also mention frailties in the company's risk of camouflaging important issues when they apply to portraying the indicators proposed by the guideline separately, but what should be considered is a joint approach, to not lose sight of sustainability (Hahn \& Lüfs, 2013).

Another frailty discussed by Hahn \& Lüfs (2013) is an non-analysis of synergies and interactions within different organizational sites using non-integrated indicators. Therefore, these indicators may not represent the organization general sustainability. This fragility, discussed by Bellen (2002) and Hahn \& Lüfs (2013), contradicts points made by Bellen (2002), which considers a segregated approach of indicators up to reflect organizational performance on sustainability. Bellen (2002) also points out the complexity involved in creating a set indicator to portray an organization's sustainability, as already discussed.

Hahn \& Lüfs (2013) also raised another aspect that, according to them, compromises the information which compose the reports based on the GRI guideline. GRI does not consider the issues from different geographical locations, so its guideline is applied to any institution, not depending on size or place where it is inserted. 
Although GRI presents guideline flaws, it is an internationally accepted model widely used by numerous companies from different sectors, which shows this company representativeness to guide the Sustainability Reports preparation.

\subsection{The brewing industry}

Historically, in all civilizations, there are references to the habit of consuming alcoholic beverage, from Mesopotamia to the Incas and Aztecs, from the Roman Empire to Ancient Egypt, there has always been a way to ferment and distill a cereal or fruit and make a drink. In Brazil, linking this to the tropical climate and the habit of refreshing drinks high consumption and low alcohol content results in full acceptance of beer before its public (CERVBRASIL, 2013).

The brewing industry has low legitimacy towards society, meaning that companies in this segment are not fully accepted by society due to the fact of producing alcoholic beverages whose use can cause health damages. Other companies also have low legitimacy towards society like cigarette and gun manufacturers, for example (Deegan et al., 2002).

The brewing industrial sector in Brazil is a differentiated oligopoly, dominated by a small number of large companies and has become rapidly internationalized (Borges \& Souza, 2009).

In 2011 and 2012, Brazil ranked third in the world beer production ranking, with a total production of 133,000 and 132,800 million hectoliters respectively, ranking right behind China and United States as shown in Table 1.

The sector has an important participation in the country's economy, as well as communicating directly with representative national sectors, either by using resources or services, and among them are: construction, transportation, energy, vehicles, pulp and paper, aluminum and glass, among others, thus having a considerable weight in the economy strategic expansion. The brewing industry handle a significant percentage of the national GDP (Gross Domestic Product) (FGV, 2008).
Borges \& Souza (2009) argue that more and more breweries have been incorporating the environmental issue and responsibility about the environment in which it is inserted along with the economic stability focus, a practice prevailing until then.

The brewing industry is a highly demanding water sector, which prompts it to seek more efficient practices in the use of this resource, guaranteeing better yield of its productive process. The average amount, considered excellent in the world, is the use of 3.75 liters of water for the production of 1 liter of beer, the beverage pasteurization and washing the packaging are the stages that most consume water in the process (Pereira \& Lima, 2013). Water main uses in industry are illustrated in Figure 1, so a small percentage reduction in water consumption on the process results in a large economy, taking into account the total volume used (Borges \& Souza, 2009).

There are factors that directly influence water consumption in the brewing industry, such as the type of packaging used (cans, returnable bottles, disposable bottles, etc.), the technology adopted for the beverage pasteurization, the industrial plant age, and others (Santos \& Ribeiro, 2005).

Therefore, the sector has a great impact on the water resources, precisely because it is intensively water demanding, besides other aspects, approached by Vieira (2014), who also mentions the energy, raw materials, caustic soda consumption, and production of solid waste, recyclable waste, industrial effluents and $\mathrm{CO} 2$ emissions.

Table 1. World beer production ranking by country of 2011 and 2012

\begin{tabular}{lcc}
\hline \multicolumn{1}{c}{ Country } & $\begin{array}{c}\text { Beer production } \\
\text { in 2011* }\end{array}$ & $\begin{array}{c}\text { Beer production } \\
\text { in 2012* }\end{array}$ \\
\hline China & 489.880 & 490.200 \\
United States & 226.480 & 229.314 \\
Brazil & 133.000 & 132.800 \\
\hline
\end{tabular}

* Production in millions of hectoliters per year. Source: Adapted from Barth \& Partner $(2012,2013)$.
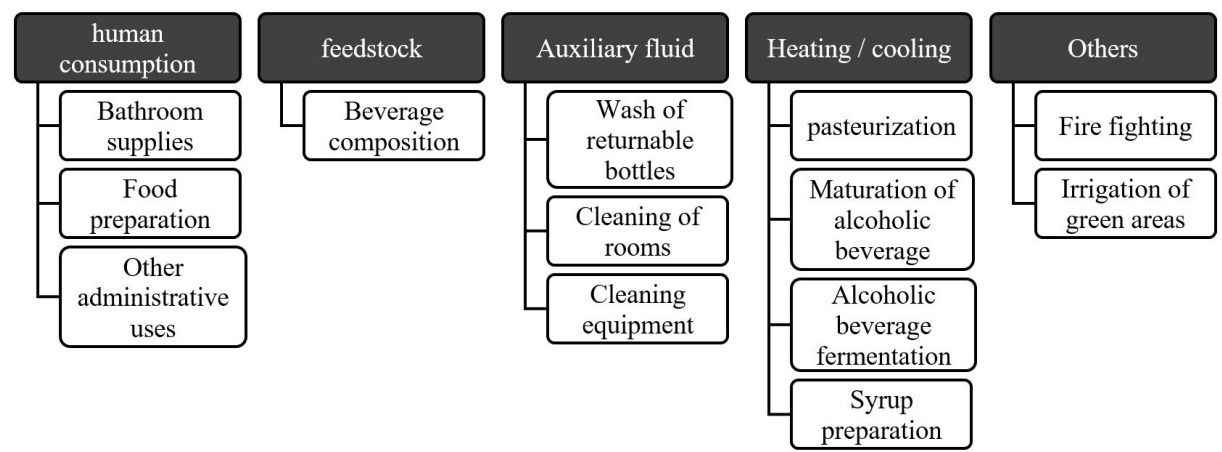

Figure 1. Main uses of water in the beverage industry. Source: Cavalcante et al. (2013). 


\section{Methodology}

All the analysis data was obtained from the Sustainability Reports contents publicly available by the companies through their websites, with a chronological cut from 2011 to 2013.

The cut is directly related to (1) access to documents, (2) the number of reports of representative companies in the domestic market, and (3) the date of publication of the documents by the companies. Given the variables, the period between 2011 and 2013 was defined as a chronological cut, a sampling rate of the Brazilian market considered representative for the sector's Sustainability Reports analysis.

From the selected reports we analyzed only the environmental issues addressed by the companies in their reports, leaving out of that work the corporate management, the social and economic scope that, according to GRI (2013) are the four pillars of a Sustainability Report.

To define the sample, the market studies of Barth \& Partner (2013) were taken into consideration, where beer production between continents, countries and companies is analyzed. Ambev (AMBEV, 2011, 2012, 2013), Brasil Kirin (Brasil Kirin, 2013, 2014), Petrópolis Group and Heineken Brasil (Heineken Brasil, 2011, 2012, 2013), which have $98 \%$ of the national market, were considered to be the sample companies representing the Brazilian market. The Sab Miller brewery was included in the sample due to its position as the second largest brewery in the world, headquartered in the United Kingdom, as the aforementioned study points out.

The research delimited the comparative studies between breweries in Brazil, Netherlands, United Kingdom and Belgium. Belgium and Netherlands, in 2012, were among the European countries that exported more beer than they imported. Another key point taken into consideration is that Belgium and Netherlands are home to the first and third largest breweries in the world, Anheuser Bush InBev (treated as AB InBev (AB InBev, 2011, 2012, 2013)) and Heineken, respectively.

Thus, the data for 2011, 2012 and 2013 of the companies presented in Chart 1 were analyzed:

One fact to be pointed is the participation of companies in holdings, with Ambev being a Brazilian subsidiary of AB InBev, Heineken Brazil's national subsidiary of Heineken and Brazil's Kirin national

Chart 1. Companies in the sample.

\begin{tabular}{|l|l|}
\hline \multicolumn{1}{|c|}{ Brazilian Market } & \multicolumn{1}{c|}{ International Market } \\
\hline Ambev & AB InBev (Belgium) \\
\hline Brazil Kirin & SabMiller (United Kingdom) \\
\hline Grupo Petrópolis & Heineken Netherlands \\
\hline Heineken Brazil & \\
\hline
\end{tabular}

Source: research data. subsidiary of Kirin Holdings Company. However, since the report publication is done by the subsidiaries, this research methodological approach remains valid and applicable.

For the report analysis, the following methodological steps were carried out:

\subsection{Indicators classification by response}

The analyzes I, II and III were based on the studies of Dias (2006), Carvalho \& Siqueira (2007) and Nossa (2002).

In order to analyze the indicators reported by the company, a response degree was made, according to Chart 2 .

\subsection{Adhesion degree (GAPIE-GRI)}

Once the indicators presented in the sustainability reports have been classified, the adherence degree, whose denomination is GAPIE-GRI, was calculated. This method allows to perceive the adhesion percentage from each company to what was requested by the GRI, being able to be between 0 and $100 \%$. This was already used in the researches of Dias (2006), Carvalho \& Siqueira (2007) and adapted for this research. Which is given by the following formula 1 :

GAPIE - GRI $=\frac{\text { Total indicators with FA }+ \text { total indicators with OJ }}{\text { Total key indicators }}$

Chart 2. Indicators classification by response.

\begin{tabular}{|c|c|}
\hline $\begin{array}{c}\text { Indicator } \\
\text { display }\end{array}$ & Display category \\
\hline \multirow{3}{*}{ Not shown } & $\begin{array}{l}\text { Not disclosed (ND) - when the information } \\
\text { is pertinent to the company's activities but } \\
\text { is not included in the report; }\end{array}$ \\
\hline & $\begin{array}{l}\text { Omitted with justification }(\mathrm{OJ}) \text { - when the } \\
\text { required data is pertinent, but is omitted } \\
\text { by the organization decision, providing } \\
\text { justification for it; }\end{array}$ \\
\hline & $\begin{array}{l}\text { Omitted }(\mathrm{O}) \text { - when an essential indicator } \\
\text { appears as presented in the index and its } \\
\text { not presented in the body of the report, } \\
\text { with no justification for it; }\end{array}$ \\
\hline \multirow{4}{*}{ Shown } & $\begin{array}{l}\text { Full adherence }(\mathrm{FA}) \text { - when all the data } \\
\text { required by the indicator was provided by } \\
\text { the company; }\end{array}$ \\
\hline & $\begin{array}{l}\text { Partial adherence (PA) - when only part of } \\
\text { the required information was submitted by } \\
\text { the company; }\end{array}$ \\
\hline & $\begin{array}{l}\text { Dubious (DUBIOUS) - when it is not } \\
\text { possible to rview whether the adhesion is } \\
\text { full or partial, due to the lack of sufficient } \\
\text { information for this conclusion. }\end{array}$ \\
\hline & $\begin{array}{l}\text { Inconsistent (INC) - when the information } \\
\text { presented by the company differs from the } \\
\text { request by the GRI indicator. }\end{array}$ \\
\hline
\end{tabular}

Source: Adapted from Dias (2006). 
FA and OJ are defined in Chart 2.

Dias (2006) highlights that, it is justified to add indicators with full adherence and omitted ones with justification in the numerator, due to the fact that the GRI allows to omit an indicator when justified.

\subsection{Effective Evidence Degree}

After the second analysis, the Effective Evidence Degree was calculated as proposed by Carvalho \& Siqueira (2007), with the objective of measuring the information reported effectively by the company in relation to the model proposed by the GRI. The calculation is given by the following formula 2 :

Effective Evidence Degree $=\frac{\text { Total indicators with FA }}{\text { Total key indicators }}$

FA is defined at Chart 2.

\subsection{IV indicators classification as to content}

After the third analysis, test fourth and fifth were performed, which are the content analysis contained in the reported responses indicators, based in the studies of Nossa (2002) and Leite et al. (2009).

Therefore, the information reported by organizations was analyzed and framed in the contente types presented in Chart 3, in order to classify the discourse contained in the GRI essential indicators report.

\section{Results and discussions}

Table 2 correlates the results by company and year:

Table 2 shows breweries publications comparison per year, the number of environmental indicators reported by each Sustainability Report, the number of Non-Declared (ND) and Full Adherence indicators

Chart 3. Information content types.

\begin{tabular}{|c|l|l|}
\hline Level & \multicolumn{1}{|c|}{ Type } & \multicolumn{1}{c|}{ Concept } \\
\hline 0 & Lack of information & When the information was not presented; \\
\hline 1 & Declarative information & Presented information only of descriptive nature; \\
\hline 2 & Non-monetary declarative information & $\begin{array}{l}\text { Presented quantitative information expressed in numbers of } \\
\text { non-financial nature; }\end{array}$ \\
\hline 3 & Monetary declarative information & $\begin{array}{l}\text { Presented quantitative information expressed in numbers of } \\
\text { financial nature. }\end{array}$ \\
\hline
\end{tabular}

Source: Adapted from Leite, Prates and Guimarães (2007) and Nossa (2002).

Table 2. Analysis results of the Sustainability Reports by company and year.

\begin{tabular}{|c|c|c|c|c|c|c|c|c|c|c|}
\hline \multirow{2}{*}{ Company } & \multirow{2}{*}{ Year } & \multirow{2}{*}{$\begin{array}{c}\text { Number of } \\
\text { environmental } \\
\text { indicators } \\
\text { reported }\end{array}$} & \multicolumn{2}{|c|}{ Indicators } & \multirow{2}{*}{$\begin{array}{c}\text { GAPIE- } \\
\text { GRI }\end{array}$} & \multirow{2}{*}{$\begin{array}{c}\text { Effective } \\
\text { Evidence } \\
\text { Degree }\end{array}$} & \multicolumn{4}{|c|}{ Speech classification } \\
\hline & & & ND & FA & & & $\mathbf{0}$ & 1 & 2 & 3 \\
\hline \multirow[t]{3}{*}{ Ambev } & 2011 & 22 & 8 & 16 & \multicolumn{2}{|c|}{$53,33 \%$} & 11 & 9 & 7 & 3 \\
\hline & 2012 & 28 & 2 & 7 & \multicolumn{2}{|c|}{$23,33 \%$} & 20 & 7 & 3 & 0 \\
\hline & 2013 & 6 & 24 & 5 & \multicolumn{2}{|c|}{$16,67 \%$} & 25 & 1 & 4 & 0 \\
\hline \multirow[t]{3}{*}{ Brazil Kirin } & 2011 & - & - & - & \multicolumn{2}{|c|}{ - } & - & - & - & - \\
\hline & 2012 & 19 & 11 & 16 & $63,33 \%$ & $53,33 \%$ & 11 & 8 & 10 & 1 \\
\hline & 2013 & 24 & 10 & 10 & $41,18 \%$ & $29,41 \%$ & 10 & 11 & 12 & 1 \\
\hline \multirow[t]{3}{*}{ Heineken Brazil } & 2011 & 12 & 18 & 9 & \multicolumn{2}{|c|}{$30 \%$} & 19 & 6 & 5 & 0 \\
\hline & 2012 & 11 & 19 & 10 & \multicolumn{2}{|c|}{$33,33 \%$} & 19 & 3 & 8 & 0 \\
\hline & 2013 & 14 & 16 & 14 & \multicolumn{2}{|c|}{$46,67 \%$} & 16 & 3 & 11 & 0 \\
\hline \multirow[t]{3}{*}{ AB InBev } & 2011 & 8 & 22 & 8 & \multicolumn{2}{|c|}{$26,67 \%$} & 22 & 0 & 8 & 0 \\
\hline & 2012 & 13 & 17 & 12 & \multicolumn{2}{|c|}{$40 \%$} & 17 & 0 & 12 & 1 \\
\hline & 2013 & 18 & 16 & 18 & \multicolumn{2}{|c|}{$52,94 \%$} & 16 & 2 & 15 & 1 \\
\hline \multirow[t]{3}{*}{ SAB Miller } & 2011 & 18 & 12 & 12 & \multicolumn{2}{|c|}{$40 \%$} & 12 & 6 & 12 & 0 \\
\hline & 2012 & 10 & 20 & 8 & \multicolumn{2}{|c|}{$26,67 \%$} & 20 & 1 & 9 & 0 \\
\hline & 2013 & 12 & 18 & 7 & \multicolumn{2}{|c|}{$23,33 \%$} & 18 & 3 & 9 & 0 \\
\hline \multirow{3}{*}{$\begin{array}{l}\text { Heineken } \\
\text { Netherlands }\end{array}$} & 2011 & 21 & 9 & 5 & \multicolumn{2}{|c|}{$16,67 \%$} & 20 & 2 & 8 & 0 \\
\hline & 2012 & 23 & 7 & 19 & \multicolumn{2}{|c|}{$63,33 \%$} & 7 & 6 & 17 & 0 \\
\hline & 2013 & 23 & 7 & 19 & \multicolumn{2}{|c|}{$63,33 \%$} & 7 & 7 & 16 & 0 \\
\hline
\end{tabular}

Source: Research data based on the analyzed Sustainability Reports. 0 - Lack of information; 1 - Declarative information; 2 - Non-monetary declarative information and 3 - Monetary declarative information. ND - Not Declared. FA - Full Adherence. 
(FA), the value obtained from GAPIE-GRI and Effective Evidence Degree and the classification of the reported indicators discourse.

It should be noted that the first Sustainability Report from Brazil Kirin was published in 2012, not having the document from the first year of the survey chronological cut, 2011. Grupo Petrópolis did not practice this type of report in any of the analyzed years, so it was withdrawn from the sample to analyze the reports. All international companies had their reports published in the years surveyed.

Regarding the indicators amount reported by the companies, it's noted that none report met all the GRI guideline indicators. The released report that had more indicators was in 2012 from Ambev and the one that had less indicators was in 2013 also from Ambev.

This may be due to a number of reasons, such as changing the company's environmental data calculation format, adapting to GRI's new G4 guideline (used in the company's 2013 report), changing the environmental perception of managers, etc. However, such justifications should be reported in the document.

A growing increase is also noted in the numbers of indicators reported each year by the companies Brazil Kirin, Heineken Brazil, AB InBev and Heineken Netherlands (Heineken Holanda, 2011, 2012, 2013). It is expected this type of behavior when reporting their performance, in order to continuously improve their data, management and, consequently, more information and indicators to be disclosed in their Sustainability Reports.

On the other hand, there was a decrease in the number of indicators released by Ambev and SABMiller (SABMiller, 2011, 2012, 2013) each year, which contrasts the expected situation from companies in the construction of their Sustainability Report published annually.

Regarding the number of Not Declared and Fully Adherent indicators, half of the reports showed a lower capacity to fully respond to an indicator than to not report indicators, suggesting that the breweries analyzed still have issues regarding the publication of environmental information in their reports.

With the exception of Brazil Kirin, all other companies had their GAPIE-GRI identical to their Effective Evidence Degree which, as presented in the methodology, GAPIE-GRI's formula incorporates in the calculation the justified omitted indicators, which is excluded in the formula of Effective Evidence Degree.

Therefore, equal results between the two calculations shows that the companies did not omit with justification any of their reported indicators, however, Brazil Kirin considered their strategic data and decided to justify their response by making public the data in 3 indicators in 2012 and 4 Indicators in 2013.

Another fact about the Effective Evidence Degree is that 13 of the 17 reports analyzed have effectively released less than half of the GRI guideline indicators.

Regarding the discourse type adopted in the answers to GRI guideline indicators, the majority have the lack of information (treated as 0 ) because they are not published in the reports. Of the reported indicators, the amount of declarative information (treated as 1) and non-monetary declarative (treated as 2) is higher than those that are monetary declarations (treated as 3). Such evidence shows that, even companies measuring their environmental impacts and actions, are not listed in the Sustainability Report with financial gain or loss by the company.

Table 3 shows the comparison between national and international reports.

Table 3 presents a average comparison of the reported Non-Declared and Full Adherence indicators, the GAPIE-GRI, the Effective Evidence Degree and the discourse classification of national and international breweries used in the research.

On the average, national and international companies have basically published the same number of indicators, but the Full Adherence and the Effective Evidence Degree of international breweries are higher than national ones.

Another point indicated in Table 3 is that, because Brazil Kirin omitted some indicators between its reports from 2012 and 2013, GAPIE-GRI differs it from the Effective Evidence Degree in the national scope.

Regarding the adopted discourse to respond the Sustainability Reporting indicators, the answers with declarative information (1) and with non-monetary declarative information (2) are greater than the monetary declarative information (3), as previously discussed for companies individually. In this scenario, Brazilian companies financially measure more indicators than international ones, but both still

Table 3. Sustainability Reporting average comparisons between national and international.

\begin{tabular}{|c|c|c|c|c|c|c|c|c|c|}
\hline \multirow{2}{*}{$\begin{array}{c}\text { Criteria } \\
\text { (Averages) }\end{array}$} & \multirow{2}{*}{$\begin{array}{c}\text { Reported } \\
\text { Indicators }\end{array}$} & \multicolumn{2}{|c|}{ Indicators } & \multirow{2}{*}{$\begin{array}{c}\text { GAPIE- } \\
\text { GRI }\end{array}$} & \multirow{2}{*}{$\begin{array}{c}\text { Effective } \\
\text { Evidence } \\
\text { Degree }\end{array}$} & \multicolumn{4}{|c|}{ Speech Classification } \\
\hline & & ND & FA & & & $\mathbf{0}$ & 1 & 2 & 3 \\
\hline Nacional & 17 & 13,5 & 10,8 & $38,4 \%$ & $35,7 \%$ & 16,4 & 6 & 7,5 & 0,6 \\
\hline Internacional & 16,22 & 14,2 & 12 & \multicolumn{2}{|c|}{$39,2 \%$} & 15,4 & 3 & 11,7 & 0,2 \\
\hline
\end{tabular}

Source: Research data based on the analyzed Sustainability Reports. 0 - Lack of information; 1 - Declarative information; 2 - Non-monetary declarative information and 3 - Monetary declarative information. ND - Not Declared. FA - Full Adherence. 
limited and less representative than the other types of speeches adopted.

\section{Final considerations}

Brazilian breweries size can be considered related to the Sustainability Reports publication, considering that all international companies have published this type of document in the analyzed chronological cut, and, in the national companies, the practice has been adopted gradually, also having a company that did not adopted this publication type.

It was verified that the environmental information dissemination in the Sustainability Reports of the brewing industrial sector, national and international, has flaws, such as the disclosure of GRI indicators with full adherence, the document external verification, financial correlation of environmental indicators, the information provided nature and the measurement of information.

External verification is a less used practice among the analyzed Sustainability Reports. Besides its limited use, when applyed, this practice still has difficulties regarding the discourse used to justify and explain its use in the report.

The non-disclosure of indicators is greater than the disclosure of indicators with full adherence, nationally and internationally, being indicators reported with full adherence less than half of what GRI suggests, demonstrating flaws on disclosing Environmental information in the sector.

The financial measurement of environmental indicators is still a less publicized practice, which indicates that the companies develop certain management about the environment in which it is inserted, but do not relate it to profit or financial loss. In this case, Brazilian companies measure financially more than the international companies analyzed, however, in a non-representative way compared to other environmental information disclosed in the report.

Even with GRI's efforts to produce comprehensive guidelines to provide better information for stakeholders, breweries need to mature their practice of publishing Sustainability Reports and to meet the information required by the guideline, with that they can achieve a complete and more transparent report.

Over the years, companies are expected to create practice in measuring and disseminating their environmental data and thereby to be more clear, consistent and complete about it in order to have a gradual evolution in their environmental disclosure.

The research had as limitation the amount of Sustainability Reports publications by the Brazilian breweries industries, since the sector is still adapting to this type of practice. Because of this, the work had a reduced report amount to compose the sample.

It is suggested, as future research, to probe deeper the financial perception of environmental indicators by the breweries and their publication in the Sustainability Reports, the sector Sustainability Reports analysis considering the forthcoming reports published by the industries and a larger number of international breweries, in order to evaluate the evidence practiced by the sector.

\section{References}

AB InBev. (2011). 2011 Global Citizenship Report. Belgium: Anheuser-Busch InBev. Retrieved in 2019, Julho 17, from https:/www.ab-inbev.com/content/dam/ universaltemplate/ab-inbev/investors/reports-and-filings/ annual-and-hy-reports/2011/AB_InBev_AR11_EN.pdf

AB InBev. (2012). 2012 Global Citizenship Report. Belgium: Anheuser-Busch InBev. Retrieved in 2019, Julho 17, from https:/www.ab-inbev.com/ content/dam/universaltemplate/ab-inbev/investors/ reports-and-filings/annual-and-hy-reports/2012/ BUD_AR12_EN_Online_v2.pdf

AB InBev. (2013). 2013 Global Citizenship Report. Belgium: Anheuser-Busch InBev. Retrieved in 2019, Julho 17, from https://www.ab-inbev.com/ content/dam/universaltemplate/ab-inbev/investors/ reports-and-filings/annual-and-hy-reports/2013/ ABI_AR13_EN_Narrative.pdf

Abreu, M. C. S., Fernandes, J. S., Soares, F. A., Silva, J. C. L. Fo (2008). Evolução da conduta de empresas siderúrgicas sob a óptica dos relatórios de evidenciação ambiental. Revista Universo Contábil, 4(4), 57-76.

AMBEV. (2011). Relatório Anual 2011. Araraquara: AMBEV. Retrieved in 2014, Setembro 23, from ri.ambev.com.br/arquivos/ambev_RA_2011.pdf

AMBEV. (2012). Relatório Anual 2012. Araraquara: AMBEV. Retrieved in 2014, Setembro 23, from www. ambev.com.br/relatorio-anual-2012/

AMBEV. (2013). Relatório Anual 2013. Araraquara: AMBEV. Retrieved in 2014, Setembro 23, from www. ambev.com.br/relatorio-anual-2013/port/index.htm

Associação Brasileira da Indústria da Cerveja-CERVBRASIL. (2013). Retrieved in 2013, September 23, from www. cervbrasil.org.br/a-cerveja/contribuicao-economica

Barth, S. \& Partner, M. (2012). Beer Production: market leaders and their challengers in the Top 40 Countries in 2011. Strasbourg: Barth-Haas Group. Recuperado em 2014, June 4, from www.barthhaasgroup.com/en/ news-and-reports/the-barth-report-hops.

Barth, S. \& Partner, M. (2013). Beer Production: market leaders and their challengers in the Top 40 Countries in 2012. Strasbourg: Barth-Haas Group. Recuperado em 2014, June 4, from www.barthhaasgroup.com/en/ news-and-reports/the-barth-report-hops.

Bellen, H. M. V. (2002). Indicadores de Sustentabilidade: uma análise comparativa (Tese de doutorado). Universidade de Santa Catarina, Trindade. 
Borges, M. S. \& Souza, S. P. N. (2009). Meio ambiente X indústria de cerveja: Um estudo de caso sobre práticas ambientais responsáveis. In Anais do V Congresso Nacional de Excelência em Gestão (pp. 1-19). Niterói: Gestão do conhecimento para a Sustentabilidade.

Brasil Kirin. (2013). Relatório de Sustentabilidade 2012. São Paulo: Brasil Kirin. Retrieved in 2014, September 23, from www.brasilkirin.com.br/pdf/ relatorio-sustentabilidade.pdf

Brasil Kirin. (2014). Relatório Anual 2013. São Paulo: Brasil Kirin. Retrieved in 2014, September 23, from relatorio.brasilkirin.com.br/pt/pdf/relatoriosustentabilidade-2013.pdf

Calixto, L. (2005). Análise de pesquisa sobre Contabilidade Ambiental no Brasil. Revista Brasileira de Contabilidade, 34(154), 23-35.

Calixto, L. (2007). Uma análise da evidenciação ambiental de companhias brasileiras - de 1997 a 2005. UnB Contábil, 10(1), 9-37.

Carvalho, F. M. \& Siqueira, J. R. M. (2007). Análise da utilização dos indicadores essenciais da Global Reporting Initiative nos relatórios sociais de empresas latino-americanas. Pensar contábil, 9(6).

Cavalcante, L. M., Machado, L. C. G. T., \& Lima, A. M. M. (2013). Avaliação do desempenhoambiental e racionalização do consumo de água no segment industrial de produção de bebidas. Ambiente e Água, 8(3), 191-202.

Cormier, D., \& Magnan, M. (2003). Environmental reporting management: a continental European perspective. Journal of Accounting and Public Policy, 22(1), 43-62. http://dx.doi.org/10.1016/S0278-4254(02)00085-6.

Deegan, C., Rankin, M., \& Tobin, J. (2002). An examination of the corporate social and environmental disclosures of BHP from 1983 - 1997: A test of legitimacy theory. Accounting, Auditing \& Accountability Journal, 15(3), 312-343. http://dx.doi.org/10.1108/09513570210435861.

Dias, L. N. S. (2006). Análise da utilização de indicadores do Global Reporting Initiative (GRI) nos relatórios sociais de empresas brasileiras (Dissertação de mestrado). Universidade Federal do Rio de Janeiro, Rio de Janeiro.

Fraas, J. W. \& Dawkins, C. E. (2011). Erratum to: Beyond acclamations and Excuses: Environmental Performance, Voluntary Environmental Disclosure and the Role of Visibility. Journal of Business Ethics, 99(3), 383-397.

Fundação Getúlio Vargas - FGV. (2008). Cerveja: uma indústria a serviço do Brasil. São Paulo: FGV. Retrieved in 2013, August 23, from http://www.cervejaebrasil.com.br.

Global Reporting Initiative - GRI. (2013). Retrieved in 2013, September 20, from www.globalreporting.org

Hahn, R., \& Lüfs, R. (2013). Legitimizing negative aspects in GRI - Oriented sustainability reporting: a qualitative analysis of corporate disclosure strategies. Journal of Business Ethics, 123(3), 401-420. http:// dx.doi.org/10.1007/s10551-013-1801-4.
Heineken Brasil. (2011). Relatório de Sustentabilidade 2011. Retrieved in 2014, September 20, from www.heinekenbrasil.com.br/arquivo/1777-AHEI Sustentabilidade_PT_Diagramacao03.pdf

Heineken Brasil. (2012). Relatório de Sustentabilidade 2012. Retrieved in 2014, September 20, from www. heinekenbrasil.com.br/arquivo/3403-AHeineken Relat\%C3\%B3rio\%20de\%20sustentabilidade $\% 20$ 2012_PT.PDF

Heineken Brasil. (2013). Retrieved in 2014, Setembro 20, from www.heinekenbrasil.com.br/?Relatoriosde-Sustentabilidade

Heineken Holanda. (2011). Summary Sustainability Report 2011. Retrieved in 2014, September 20, from https://secure.theheinekencompany.com/latest-reports

Heineken Holanda. (2012). Retrieved in 2014, Setembro 20, from https://secure.theheinekencompany.com/ latest-reports

Heineken Holanda. (2013). Retrieved in 2014, Setembro 20, from https://secure.theheinekencompany.com/ latest-reports

Leite, G. A. F., Prates, L. A. \& Guimarães, T. N. (2009) Análise dos níveis de evidenciação dos relatórios de sustentabilidade das empresas brasileiras A+ do Global Reporting Initiative (GRI) no ano de 2007. Revista de Contabilidade e Organizações - USP, 3(7):43-59.

Nossa, V. (2002). Disclosure ambiental: uma análise do conteúdo dos relatórios ambientais de empresas do setor de papel e celulose em nível internacional (Tese de doutorado). Faculdade de Economia, Administração e Contabilidade, Universidade de São Paulo, São Paulo.

Pereira, A. M., \& Lima, D. A. L. (2013). Os impactos e as oportunidades de negócios: estudos de casos. In Anais do IV Encontro Nacional da Anppas. Brasília: Anppas.

Ribeiro, M. S. (2010). Contabilidade ambiental (2a ed.). São Paulo: Ed Saraiva.

Rosa, F. S; Ferreira, A. C. S.; Ensslin, S. R. \& Ensslin, L. (2010) Evidenciação Ambiental (EA): Contribuição da metodologia multicritério para identificação dos aspectos financeiros para a gestão ambiental. Contabilidade Vista \& Revista. 21(4), 27-61.

Rover, S., Tomazzia, E. C., Murcia, F. D. R., \& Borba, J. A. (2012). Explicações para a divulgação voluntária ambiental no Brasil utilizando a análise de regressão em painel. Revista ADM, 47(2), 217-230. http://dx.doi. org/10.5700/rausp1035.

SABMiller. (2011). Sustainable Development Summary Report 2011. Retrieved in 2014, September 20, from http://www.sabmiller.com/docs/default-source/investordocuments/reports/2011/sustainability/sustainabledevelopment-report-2011.pdf?sfvrsn=4

SABMiller. (2012). Sustainable Development Summary Report 2012. Retrieved in 2014, September 20, from http://www.sabmiller.com/docs/default-source/investordocuments/reports/2012/sustainability/sustainabledevelopment-report-2012.pdf?sfvrsn=4 
SABMiller. (2013). Sustainable Development Summary Report 2013. Retrieved in 2014 September 20, from http://www.sabmiller.com/docs/default-source/investordocuments/reports/2013/sustainability/sustainabledevelopment-report-2013.pdf?sfvrsn $=4$

Santos, C. B. (2011). Contabilidade Ambiental (Dissertação de mestrado). Universidade Técnica de Lisboa, Lisboa.

Santos, M. S. \& Ribeiro, F. M. (2005). Cervejas e refrigerantes série $P+L$. São Paulo: CETESB.

Sucena, E. S. \& Marinho, M. M. O. (2014). Oportunidades da evidenciação ambiental no setor de produção de cervejas do Brasil. In Anais do Encontro Internacional sobre Gestão Empresarial e Meio Ambiente (pp. 1-14). São Paulo: Engema.
Trieweiller, A. C., Peixe, B. C. S., Tezza, R., Bornia, A. C. \& Campos, L. M. S. (2012). Measuring environmental management disclosure in industries in Brazil with Item Response Theory. Journal of Cleaner Production. 47, 298-305.

Vellani, C. L. \& Ribeiro, M. S. (2009). Sistema contábil para gestão da ecoeficiência empresarial. Revista Contabilidade Financeira, 20(49), 25-43.

Vieira, T. M. (2014). Sistema de gestão ambiental e sua contribuição para o desempenho ambiental: Estudo de caso em uma indústria de bebidas de grande porte (Trabalho de conclusão de curso). Escola Politécnica, Departamento de Engenharia Ambiental e Sanitária, Universidade Federal da Bahia, Salvador. 